\title{
Role of SMEs in Oman: Perspectives of future Employment and
}

\section{Protection Policy Response}

\author{
Swadhin Mondal, ${ }^{1}$ \\ swadhin@unizwa.edu.om \\ Abdullah A1-Shukaili ${ }^{1}$, \\ a.alshukaili@unizwa.edu.om \\ Norizan Mohd Kassim ${ }^{1}$ \\ nkassim@unizwa.edu.om \\ Mohd Zain ${ }^{2}$ \\ mzain@squ.edu.om
}

1 Department of Management, University of Nizwa, Oman

2 Department of Management, Sultan Qaboos University, Oman

Keywords: SMEs, labor market challenges, projection of job opportunities,

GEM, Oman

\begin{abstract}
:
SMEs is consider as an important component of economic development, create job opportunities, and bring innovation and social welfare. Empirical evidence shows that SMEs plays a major role in creating employment in developed countries. In developing countries there are mixed results-- there is no direct relation between entrepreneurship and employment growth. However, there are very few studies investigates the links between the growth of SMEs and the growth of employment creation in oil dependent economy. Present study investigates the growth of future employment creation across the size of SMEs by using recent survey data conducted by Global Entrepreneurship Monitor (GEM) in Oman. Regression analysis was used to examine the association with future job creation and other factors influencing job creation. Study found that early stage entrepreneurs expecting to provide more than two times of current level of employment by next 5 years. However, established business (EB) entrepreneur's expected employment growth is negative. This means that after 5 years' job opportunity will be
\end{abstract}


reduced in established SMEs. Our regression result shows that the male entrepreneur who have higher level of qualification and earning higher income from the business are more likely to create more jobs in next 5 years and so. The study also found that the self-perceived innovation and creativity have positive and significant relation with job creation in future. However, the skills, experience and optimism towards business environment have negative relation with future job creation.

\section{Background:}

SMEs is consider as an important component of economic development, create job opportunities, bring innovation and social welfare(Schumpeter 1934; Acs 2008; Tamvada 2010, Wennekers and Thurik 1999; Baumol 2002,Botha et al., 2007, Phillips et al., 2014; Haque et al.2017). To accelerate the growth of the SMEs many international aid agency provide a large amount of financial support for developing SMEs in developing countries. However, how far these support programme really effective to ensure the growth and sustainability of SMEs in developing countries. Empirical evidence shows that SMEs plays a major role in creating employment in developed countries. A recent study shows that in low and middle income countries SMEs provides more than two-third of the formal employment( Kok et al 2013). A study by Ayyagari et al (2014) shows that SMEs have largest share of job creation as well as employment growth. The study also found that small and young firm have higher rate of job creation but established firm have largest employment as compared to the other firms( Ayyagari et al 2011). Also a few studies found that micro enterprises experiences highest growth of employment - it contributes 58 percent of total employment growth in European union(Kok et al 2011). However, a study by Ghani(2011) found that there is no direct relation between entrepreneurship and employment growth in developing countries. It shows that the growth of entrepreneurship and job creation depend on the quality of physical infrastructure, education and quality of the labor force. SMEs experiences higher growth and creates more job opportunities where the firms gets good physical infrastructures and skills labours. However, in contrast, a recent study by Beck and Kunt (2014) argued that in developing countries SMEs have no significant role to promote employment growth and poverty reduction compared to the large firms - large firms have higher contribution on job creation in influence economic growth. Numerous studies also show that age rather than size of a firm is more important factors affecting employment growth-young firms generate more jobs but one-half of the 
newly startups firm able to sustain for next five years and only few percentage of firms emerge as high growth firm that contribute for future job creation(OECD 2017). However, there are very few studies investigates the links between the growth of SMEs and the growth of employment creation in oil revenue based economy. Over the past three decades most of the oil dependent countries utilize the oil revenue and developed physical infrastructure and made significant economic progress. Recently most of the oil dependent countries are focusing on the diversification of economy from oil sector to other section-especially focusing development of entrepreneurship and SMEs. Present study investigates the growth of future employment creation across the size of SMEs by using recent survey data conducted by Global Entrepreneurship Monitor (GEM) in Oman.

Oman, like other oil dependent countries, made a significant economic progress and also social transformation. Utilized oil revenue and developed infrastructure, create job opportunities and improve the social welfare. A large number of young populations specially the females are completing their higher education and ready to join in the labor market. However, recently the country experiencing oil revenue crisis that have multiplier effect on economic activities especially on creation of employment in the labor market. Previously, like other GCC countries, majority of the people in Oman prefers to rely on government job and in someway it was managed by the government. However, the recent experience shows that government alone unable to meet challenges facing in the labor market. World Bank recent data shows that over the last 10 years' labor participation rate in Oman increased from 60.02 percent in 2010 to 72.20 percent in 2019. This means that in every year the economy need to create job in addition to 1.2 percent of current labor force. Recently government implemented various policies to strengthening economic, business activities and supporting SMEs to increase employment opportunities. In this context this paper examine how small and medium scale enterprises will ensure employment opportunity by using recent global entrepreneurship monitor(GEM) survey data in Oman. Therefore, the objective of the study are-(1) to examine the how SMEs will able to fulfil the future need and expectation of creation of employment opportunities; and (2) to investigates the major determine factors influencing job creation through various types of entrepreneurs in Oman.

\section{Data and Methodology:}

The study uses GEM (Global Entrepreneurship Monitor) Adult Population Survey(APS) data from Oman. GEM-Oman survey was conducted during June-August 2019. This survey collected information from the adult's population age group 18 to 64 years across Oman. It covered 2000 households, and the respondent was selected randomly. The survey was conducted by random telephone calls using a random digital dialing code and using a structuring questionnaire prepare by the GEM consortium. The questionnaire consists of more than 100 variables related to entrepreneurial development activities, type entrepreneurs, 
number current employees, expected job creation in future, perception, attitude, necessary skills, business environment, and also innovations.

We analyzed the data by using standard econometrics and statistical tools. Regression analysis was used to examine the association with future job creation and other factors influencing job creation. Analysis was done using STATA program and analyzing various indicators such as entrepreneur's skills and experience, self-perceived innovation and creativity, business environment, entrepreneur's level of education, age, gender and income from the business. Therefore, to investigate the major influencing factors associated with future job creation we specify the following equation:

$\mathrm{JC}_{\mathrm{i}}=\alpha_{1 \mathrm{i}}+\beta_{1 \mathrm{i}} \mathrm{X}_{\mathrm{ij}}+\varepsilon_{\mathrm{ij}}$

Where, JC denotes the future job creation by various type of entrepreneurs such as nascent entrepreneurs and EB entrepreneurs. $X_{\mathrm{ij}}$ denotes the explanatory variables and $\beta$ is the corresponding coefficient of the explanatory variables.

\section{Results:}

The study found that presently the average number of employees in SMEs is 12.1 and nascent entrepreneurs are providing more job opportunities compared to owner manager entrepreneurs. However, in future nascent entrepreneurs expecting that can offer more than doubles percentage of jobs by 5 years. However, owner manager entrepreneur's jobs creation rate is negative.

\section{Figure 1: Expected Job Opportunities in Nascent and EB Entrepreneurs in Oman}

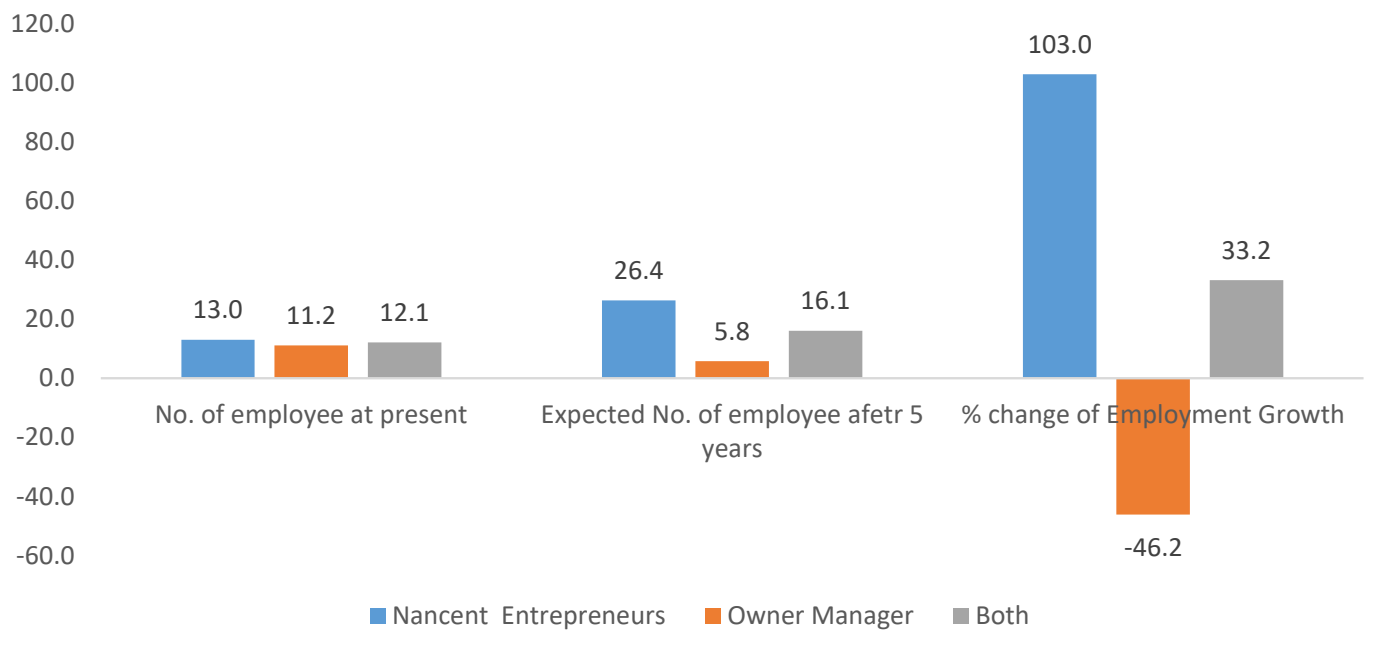

Source: GEM APS survey data 2019, Oman 
This means that after 5 years' job opportunity may be reduced in the SMEs under owner manager. However, in combine all other SMEs, the employment opportunity will increase by 33.2 percent after 5 years.

Figure 1 shows the expected number of jobs to be created after five years for both early-stage entrepreneurial and also for established firms. Both charts display a positive estimate regarding the future employment generation and there is not much difference in the estimate between two firms. Majority of both type of firms anticipates employment generation of 1-5 jobs

Figure 2: Early-stage entrepreneurial activities and EBs by expected number of employees in five years

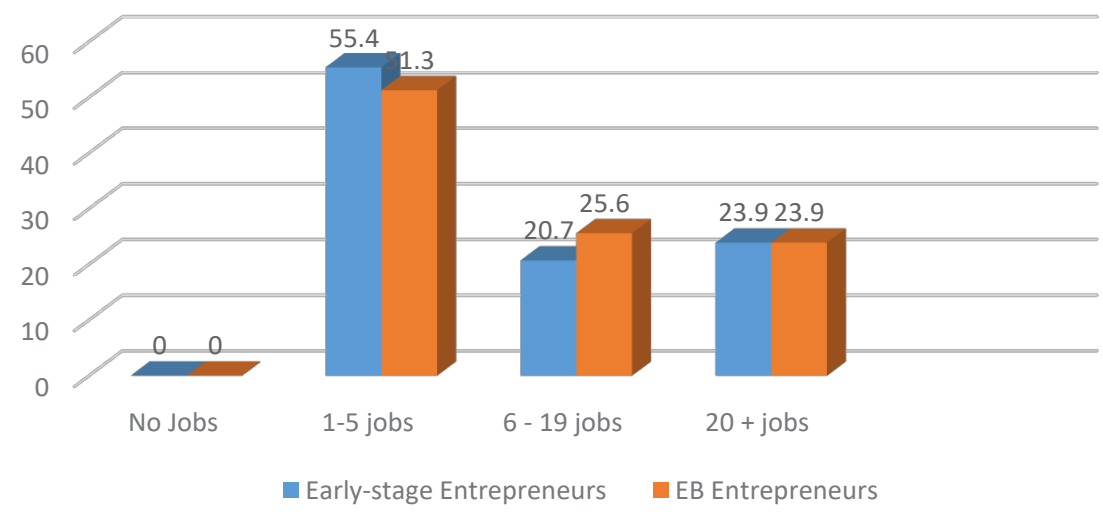

Table 1 shows that the proportion of cases with expectations of high growth in job creation is significantly high - more than 19.95 percent for early-stage entrepreneurs, especially due to new entrepreneurs' aspirations. However, established owner-managers show a similar percentage of cases of high job expectation is 14.30 percent. The proportion of early-stage businesses that have employees now or in five years is really discrete (4.78\%) evidencing the micro and small dimension of most entrepreneurial activities which is not expected to change significantly in the short term.

Table 1: Complementary indicators on expectations of job creation for early-stage firms and EBs for the year 2019

Concept

\% 18-64 pop: TEA any jobs now or in 5 years

\% 18-64 pop: TEA expects more than 19 jobs in 5 years

$\%$ within TEA: High job expectation (10+ jobs and over 50\% in 5 years) 
\% within EB: High job expectation (10+ jobs and over 50\% in 5 years)

\section{Source: GEM APS Survey, 2019}

The study also found that the young entrepreneurs expecting to offer more jobs in future as compared to older entrepreneurs. Entrepreneurs age group 35 to 44 years are expecting that they can offer more than 4 times of the current number of employees. However, in case of EB entrepreneurs are expecting negative growth of employment in future. Similarly, entrepreneurs who hold primary and bachelor level degree are expecting to create more job in future for both TEA as well EB entrepreneurs. Similarly the EB entrepreneurs earing lower income ( 0 to 600 OMR) expecting more employment growth (137 percent) compared to the high income entrepreneurs. However, in case of TEA entrepreneurs, results show that high income entrepreneurs (1921 to 2400 OMR) expecting to provide more jobs in future as compared to others firms.

Table 2: Expected number of Job Creation by Nascent and EB Entrepreneurs in Oman in Next 5 Years

\begin{tabular}{|c|c|c|c|c|c|c|}
\hline & \multicolumn{3}{|c|}{ Nascent Entrepreneurs } & \multicolumn{3}{|c|}{ EB Entrepreneurs } \\
\hline & $\begin{array}{l}\text { No. of } \\
\text { employ } \\
\text { ee at } \\
\text { present }\end{array}$ & $\begin{array}{l}\text { Expected } \\
\text { No. of } \\
\text { employee } \\
\text { after } 5 \text { years }\end{array}$ & $\begin{array}{c}\% \\
\text { chang } \\
\mathrm{e} \\
\text { (Grow } \\
\text { th) }\end{array}$ & $\begin{array}{l}\text { No. of } \\
\text { employ } \\
\text { ee at } \\
\text { present }\end{array}$ & $\begin{array}{l}\text { Expected } \\
\text { No. of } \\
\text { employee } \\
\text { after } 5 \\
\text { years }\end{array}$ & $\begin{array}{c}\% \\
\text { change } \\
\text { (Growt } \\
\text { h) }\end{array}$ \\
\hline Gender & & & & & & \\
\hline Male & 15.19 & 33.85 & $\begin{array}{c}122.8 \\
4 \\
110.5\end{array}$ & 13.23 & 5.17 & -60.92 \\
\hline Female & 1.9 & 4 & 3 & 6.44 & 7.48 & 16.09 \\
\hline $\begin{array}{l}\text { Age } \\
18-24\end{array}$ & & & 335.9 & & & \\
\hline Years & 2.13 & 9.26 & 1 & 6.22 & 9.58 & 53.95 \\
\hline 25-34 years & 9.16 & 10.86 & $\begin{array}{l}18.55 \\
405.6\end{array}$ & 7.70 & 5.33 & -30.71 \\
\hline $35-44$ years & 7.65 & 38.67 & 4 & 14.50 & 5.19 & -64.22 \\
\hline $45-54$ years & 12.50 & 14.75 & $\begin{array}{l}18.00 \\
125.6\end{array}$ & 27.00 & 1.71 & -93.65 \\
\hline $55-64$ & 106.00 & 239.20 & 6 & 4.00 & 2.00 & -50.00 \\
\hline $\begin{array}{l}\text { Education } \\
\text { Primary } \\
\text { School }\end{array}$ & 107.67 & 204.60 & 90.03 & 1.75 & 3.75 & 114.29 \\
\hline
\end{tabular}




\begin{tabular}{|c|c|c|c|c|c|c|}
\hline & & & & & & \\
\hline secondary & 146 & & 214.4 & & 280 & \\
\hline Seni. & & & 143.0 & 15.12 & 5.09 & $-10.5 J$ \\
\hline secondary & 5.00 & 12.15 & $\begin{array}{c}3 \\
1771\end{array}$ & 11.31 & 12.08 & 6.80 \\
\hline Bachelor & 15.89 & 44.04 & 7 & 4.73 & 7.36 & 55.77 \\
\hline $\begin{array}{l}\text { Post } \\
\text { graduate }\end{array}$ & 26.00 & 7.17 & $\begin{array}{c}-72.44 \\
185.1\end{array}$ & 12.00 & 4.33 & -63.89 \\
\hline $\mathrm{PhD}$ & 13.50 & 38.50 & 9 & 0.00 & 0.00 & 0.00 \\
\hline $\begin{array}{l}\text { Income gr } \\
0-600\end{array}$ & & & & & & \\
\hline $\begin{array}{l}\text { OMR } \\
601-960\end{array}$ & & 70.67 & & 1.14 & 2.71 & 137.50 \\
\hline $\begin{array}{l}\text { OMR } \\
961-1400\end{array}$ & 14.5 & 24.80 & 71.03 & 1.00 & 1.00 & 0.00 \\
\hline $\begin{array}{l}\text { OMR } \\
1441-1920\end{array}$ & & 11.25 & & 2.00 & 3.00 & 50.00 \\
\hline $\begin{array}{l}\text { OMR } \\
1921-2400\end{array}$ & 2.67 & 3.80 & $\begin{array}{l}42.50 \\
339.2\end{array}$ & 8.00 & 11.50 & 43.75 \\
\hline OMR & 4.67 & 20.50 & 9 & 12.64 & 2.87 & -77.33 \\
\hline $\begin{array}{l}2400 \text { and } \\
\text { above }\end{array}$ & 10.22 & 12.85 & 25.72 & 18.93 & 12.14 & -35.85 \\
\hline All & & & 102.8 & & & \\
\hline category & 13.01 & 26.39 & 4 & 11.17 & 5.85 & -47.64 \\
\hline
\end{tabular}

Source: GEM APS survey data 2019, Oman

Our regression result shows that the male entrepreneur who have higher level of qualification and earning higher income from the business are more likely to create more jobs in next 5 years and so (Table 3 ). The study also found that the self-perceived innovation and creativity have positive and significant relation with job creation in future. However, the skills, experience and optimism towards business environment have negative relation with future job creation.

Table 3: Determine factors influencing future job creation

\begin{tabular}{lcrcc}
\hline & \multicolumn{2}{c}{ Nascent Entrepreneurs } & \multicolumn{2}{c}{ EB Entrepreneurs } \\
\cline { 2 - 5 } & Coefficient & T-values & Coefficient & T-values \\
\hline Age & -0.06 & -0.87 & -0.21 & -1.14 \\
Age $^{2}$ & 0.00 & 1.23 & 0.03 & 1.30
\end{tabular}




\begin{tabular}{lcccc} 
Gender_male & $0.58^{* * *}$ & 2.61 & 0.69 & 1.18 \\
Income & $0.05^{* * *}$ & -2.11 & 0.05 & 1.27 \\
Education level & $0.15^{* *}$ & 1.97 & -0.23 & -1.25 \\
Skills and Experience & -0.05 & -0.81 & $0.32^{* *}$ & 1.97 \\
Fear to failure in business & -0.09 & -1.37 & 0.17 & 1.06 \\
Self-perceived creativity & -0.02 & -0.38 & $-0.29^{* * *}$ & -1.83 \\
Perceived optimisms & $-0.13^{* *}$ & -1.93 & 0.06 & 0.36 \\
Household size & -0.01 & -0.31 & -0.04 & -0.63 \\
Constant & 4.16 & 3.24 & 4.14 & 1.22 \\
\hline & Number of obs $=138$ & Number of obs $=46$ \\
& R-squared=0.1582 & R-squared = 0.2519 \\
& F( 10, 127) $=2.39$ & \multicolumn{3}{c}{$\mathrm{F}(10,35)=1.81$} \\
\hline
\end{tabular}

\section{Conclusion and Practical Implications:}

The study found that new entrepreneurs are expecting to create more than 100 percent jobs in next 5 years. Conversely, SMEs under owner-manager are afraid of creating new job opportunities in future - negative growth of employment. However, combining all SMEs in Oman can be created 33 percent of additional jobs in next 5 years that can be helpful to meet the current labor market challenges in Oman. This results have some important policy implications to solve some of the issues facing in labor market. Newly established entrepreneurs especially young entrepreneurs are more confident that they can generate more jobs in future and their self-perceived innovation and creativity natures bring that confidence. The study suggest that government can provide support to motivate them and at the same time government should identify the issues why SMEs under owner manager expecting negative growth of employment in future. The new insights can be helpful to the policy maker to make a better policy meet challenges that the economy is facing currently.

\section{References:}

Schumpeter, J. A. (1934). The theory of economic development. Cambridge, MA: Harvard University Press.

Acs, Z., Desai S and Hessels J. (2008). Entrepreneurship, economic development and institutions. Small Business Economics, 31:219-234 DOI 10.1007/s11187-008-9135-9

Tamvada, J.P.(2010). Entrepreneurship and welfare; Small Business Economics; 34: 65. https://doi.org/10.1007/s11187-009-9195-5 
Wennekers, A. R. M., \& Thurik, A. R. (1999). Linking entrepreneurship and economic growth. Small Business Economics, 13(1), 27-55

Botha, M., Nieman, G. and van Vuuren, J. (2007), Measuring the effectiveness of the Female Entrepreneurship Programme on potential, start-up and established female entrepreneurs in South Africa. South African Journal of Economic and Management Sciences, 10(2): 163183

Phillips, M., Moos, M. and Nieman, G. (2014), The impact of government support initiatives on the growth of female businesses in Tshwane South Africa. Mediterranean Journal of Social Sciences, 5(15): 85-92.

Haque, M.R., Kabir, M.Z., Rahman, M.M., Chowdhury, S.P \& Islam, S. 2017, Entrepreneurial Intentions: A Study on Students from Countryside University, Asian Economic and Financial Review, Vol. 7, No. 10, pp. 972-980.

Kok JD, Deijl C and Veldhuis .2013). Is Small Still Beautiful? Literature Review of Recent Empirical Evidence on the Contribution of SMEs to Employment Creation.

Meghana Ayyagari \& Asli Demirguc-Kunt \& Vojislav Maksimovic, 2014. "Who creates jobs in developing countries?," Small Business Economics, Springer, vol. 43(1), pages 75-99, June

Meghana Ayyagari; Asli Demirguc-Kunt and Vojislav Maksimovic, (2011), Small vs. young firms across the world: contribution to employment, job creation, and growth, No 5631, Policy Research Working Paper Series, The World Bank

Kok JD, Verhoeven P, Timmermans N, Westhof JSF (2011). Do SMEs create more and better jobs? Report prepared by EIM for the European Commission DG Enterprise and industry, Brussels, European Commission file:///C:/Users/Swadhin/Downloads/do-smes-create-moreand-better-jobs_en.pdf

Kok, J.M.P.; Vroonhof, P.; Verhoeven, W.; Timmermans, N.; Kwaak, T.; Snijders, J.; Westhof, F. 2011. "Do SMEs create more and better jobs?", Report prepared by EIM for the European Commission DG Enterprise and industry, Brussels, European Commission.

Ejaz Ghani \& William R. Kerr \& Stephen D. O'Connell, 2011. "Who Creates Jobs?," World Bank Other Operational Studies 10072, The World Bank. 
OECD.(2017). Small Businesses, Job Creation And Growth: Facts, Obstacles And Best Practices.

https://www.oecd.org/cfe/smes/2090740.pdf 